\title{
Rhetorical Muslims: Islam as Witness in Western Christian Anti-Jewish Polemic
}

\author{
Musulmanes retóricos: el Islam como testigo en \\ la polémica cristiana anti-judía en occidente
}

\author{
Ryan Szpiech \\ University of Michigan, USA
}

\begin{abstract}
Aunque los escritores del s. XII como Pedro Alfonso y Pedro el Venerable de Cluny atacaron las ideas musulmanas sobre Jesús y María, los autores polémicos de los ss. XIII y XIV a veces presentaron las mismas ideas de manera positiva y describieron al musulmán como un «testigo» de las ideas cristianas ante los judíos. En los textos del dominico Ramon Martí, el Corán mismo sirve como una «prueba» de las doctrinas cristianas sobre Jesús y María y en textos como el Mostrador de justicia de Abner de Burgos/Alfonso de Valladolid, a los musulmanes se los describe como «nazarenos». El estudio de estas imágenes permite distinguir entre la representación de los musulmanes en los textos anti-judíos y su representación en los textos anti-islámicos. Este artículo sugiere que, en los textos anti-judíos de los ss. XIII y XIV, son más determinantes las normas de la polémica anti-judía que el juicio sobre el islam que se observa en la polémica anti-musulmana.
\end{abstract}

Palabras clave: representación del Islam; polémica judío-cristiana; polémica islamo-cristiana; Ramon Martí; Alfonso Buenhombre; Alfonso de Valladolid.

\begin{abstract}
Although twelfth-century writers such as Petrus Alfonsi and Peter the Venerable of Cluny attacked Muslim ideas about Jesus and Mary, polemical authors of the thirteenth and fourteenth centuries sometimes presented the same ideas in a positive light, describing the Muslim as a "witness" to the Jews of the truth of Christian ideas. In texts by the Dominican Ramon Martí, the Qur'ān itself serves as a "proof" of Christian doctrines about Jesus and Mary and in texts such as the Mostrador de justicia of Abner de Burgos/Alfonso de Valladolid, Muslims are described as "Nazarenes." The study of these images allows us to distinguish between the representation of Muslims in anti-Jewish and anti-Islamic texts. This article proposes that the representation in anti-Jewish texts was more determined by the norms of those texts than by the ideas about Islamic sources contemporary anti-Muslim writing itself.
\end{abstract}

Keywords: Representation of Islam; JewishChristian polemic; Christian-Muslim polemic; Fourteenth century; Ramon Martí; Alfonso Buenhombre; Alfonso de Valladolid.

* This research is part of a European Research Council project entitled, "The Intellectual and Material Legacies of Late Medieval Sephardic Judaism: An Interdisciplinary Approach", directed by Dr. Esperanza Alfonso (CSIC). I wish to thank the ERC for its support and Dr. Alfonso as Principle Investigator of the project. I am also grateful to David Nirenberg, Uri Shachar and Hussein Fancy for their helpful comments and criticism on earlier drafts. 
Although it has been alleged that the Florentine Dominican polemicist Riccoldo da Monte Croce (d. 1320) - best known for his influential anti-Muslim polemic, Contra legem Sarracenorum (Against the Law of the Saracens) — wrote an anti-Jewish polemic entitled Contra errores Judeorum (Against the Errors of the Jews), no text has survived and very little evidence actually attests to the existence of such a work. ${ }^{1}$ Monte Croce's only surviving anti-Jewish writing can be found in part of his last work, the Libellus ad nationes orientales (Little Book to the Oriental Nations), which was written after his return from Baghdad to Italy in the early fourteenth century. It includes a section against Nestorians and Jacobites, a section on Jews, a short section on Tartars (or Mongols), and a list of general rules for missionaries. ${ }^{2}$ In his prologue to the Libellus, he explains that just as Jews "seem to differ more" (magis videntur distare) from orthodox Christians than Christian heretics, Muslims differ more than Jews, and Tartars more than Muslims. By contrast, the facility with which each group can be converted is inverse to that of their "distance" from Christianity: "But nevertheless, concerning the nearness [to Christianity] and conversion, it is completely the contrary to what was said before, namely, with experience as a witness, Tartars are more easily converted than Saracens, Saracens [more easily] than Jews, and Jews [more easily] than [heretical] Christians". ${ }^{3}$

This observation places Jews and Muslims on a sliding scale of worth, from a Christian perspective, based on their propinquity to Christian truth and their willingness to accept baptism. Muslims, by virtue of their relative distance from Christianity, here present less of a theological challenge than Jews, whose intimate link with Christianity makes their resistance to conversion all the more egregious. In expres-

${ }^{1}$ On this work, see Schreckenberg, Die christlichen, p. 357; Dondaine, "Ricoldiana", p. 143.

2 On the Libellus, see Dondaine, "Ricoldiana", pp. 137-142. The Libellus is found in Florence, Biblioteca Nazionale, MS Conv. Sopp. C. 8. 1173, fols. 219r-244r, and the section De Iudaeis is found on fols. $228 \mathrm{v}-241 \mathrm{r}$. We can compare this to a statement of king Alfonso $\mathrm{X}$ of Castile (d. 1284) in his Espéculo, Book 5, título 8, Law 35 (V.8.35.d), "Ssi el que ffuese de nuestra Ley quissiesse conuertir al judio, que non lo podrie ffazer tan ayna como al moro o al gentil". See Alfonso X, Espéculo, p. 242.

3 "Sed tamen quantum ad effectum appropinquationis et conuersionis est totum contrarium in predictis, nam, experientia teste, tartari facilius conuertuntur quam sarraceni, et sarraceni quam iudei, et iudei quam christiani”. Florence BN Conv. Sopp. C. 8. 1173, fols. 219v-220r. 
sing this polemical fiction, Riccoldo's words evoke concisely one of the central issues determining medieval Western ideas about both Muslims and Jews, the tension between the practical challenge they presented to Christian power within and beyond the borders of Christendom, and their theological meaning to Christian belief alongside other non-Christian groups. Although the balance in medieval Christian thought between, in Benjamin Kedar's words, mission and crusade, led to varying responses to non-Christian groups, nevertheless, Jews and Muslims were connected in Latin polemical texts as early as the twelfth century, and among Eastern Christians writing in Arabic, examples survive from as early as the eighth. ${ }^{4}$ Many have noted that Muslims and Jews became increasingly linked in twelfth- and thirteenth-century polemics, and by the fourteenth, they were often conflated into a single legal category as well. While scholars such as R.I. Moore have seen the association of groups such as Jews, heretics, and lepers as part of a single phenomenon of increasing Christian exclusion of social minorities, others such as John Tolan have cautioned against exaggerating "this phenomenon of lumping together the enemies of the Catholic faith". ${ }^{5}$ Yet however closely Jews and Muslims were classified with heretics and lepers, it is clear that, in Western writing, they were increasingly associated with each other beginning in the twelfth century, and such linking is evident in a large corpus of sources, including legal, polemical, and literary texts.

\section{The "Muslim Connection"}

As a result, numerous critics have begun to explore what Jeremy Cohen has called "the Muslim Connection" in Christian anti-Jewish polemical sources, proffering evidence of the influence of anti-Muslim polemic on Adversus Iudaeos writing. ${ }^{6}$ Central to this consideration, as Cohen proposes it, is the question of how the anti-Muslim polemical

${ }^{4}$ Griffith, "Jews and Muslims", p. 65, has cited examples as early as a 781 letter of the Nestorian patriarch Timothy I naming Muslims as "the new Jews among us". See also Griffith, The Church; and Kedar, Crusade.

${ }_{5}$ Moore, The Formation of a Persecuting Society, p. 62; Cohen, Living Letters, p. 158 n. 29; and Tolan, Saracens, p. 278. See also Daniel, Islam, pp. 213-218. On the linking of Jews and Muslims in canon law, see Kedar, "De iudeis", pp. 207-213.

${ }^{6}$ Cohen, "The Muslim Connection", pp. 141-45. 
tradition may have influenced or catalyzed contemporary anti-Jewish arguments. At the same time, however, another aspect of this "Muslim connection" has gone relatively unexplored, although many critics have touched on it in passing, namely, the role that Muslims and Muslim texts actually play, as characters or concepts, within anti-Jewish polemic. The reason for this unbalanced focus is that such images of Muslims in anti-Jewish polemic have been considered as part of antiMuslim rather than anti-Jewish discourse, and little distinction has been made between representations of Muslims in different kinds of polemical texts. Mention of the perceived commonality of Islamic and Christian beliefs (e.g. Muslim reverence of Jesus, belief in Mary, belief in the error of the Jews, etc.) was a regular part of anti-Muslim literature from the very earliest Christian discussions, appearing at least as early as the letters of the Syriac Orthodox Bishop Jacob of Edessa (d. 708), and constituting an argument in the Apology of Al-Kindì (an Arabic anti-Muslim polemic, possibly of the ninth or tenth centuries) and in the Latin polemics based on it after the twelfth century. ${ }^{7}$ Yet despite this well-recognized tradition arguing, in Norman Daniel's words, "the duality in Islam of truth and untruth", ${ }^{8}$ the presence of similar ideas in the construction of anti-Jewish arguments has yet to be considered as a separate issue apart from the question of how Muslims were represented in anti-Muslim polemics. ${ }^{9}$

Rather than simply repeating arguments from anti-Muslim literature, the representation in Western Christian anti-Jewish texts from the thirteenth and fourteenth centuries - that is, texts whose principal purpose consists in refuting or attacking Judaism - constitutes a strategic invocation of Muslims or Muslim texts to support Christianity. What is presented as "the law of the Saracens" (or "law of Muhammad") is not attacked as directly or as scathingly as in deliberate anti-Muslim tracts and is sometimes not attacked at all. Instead, the Muslim character-whom I will call here the "rhetorical Muslim", by adapting the

7 Griffith, "Jews and Muslims", pp. 71-76, especially p. 73; and Griffith, The Church, pp. 31-32. On this common trope of anti-Muslim literature, see Daniel, Islam, pp. 186-200. On the al-Kindi text, see below, n. 15.

${ }^{8}$ Daniel, Islam, p. 186.

9 The potential distortions that threaten such comparative discussions are evident in the well-intentioned but deeply flawed study by Cutler and Cutler, The Jew as Ally, in which the authors seek to connect the rise of anti-Semitism in Western Europe to what they call "anti-Muslimism". For a critique of the Cutlers' work, see the review by Cohen. 
well-known concept of the "hermeneutical Jew" who unwittingly testifies to the truth of Christian ideas - comes to affirm Christian beliefs before an imagined Jewish character or reader. ${ }^{10}$ By looking at such portrayals, this article proposes to consider the representation of Muslims in later medieval anti-Jewish polemics in order to demonstrate that the idea of Muslims and Muslim sources took on, on limited occasions, a purely symbolic, rhetorical role for Christian polemicists as witnesses to Christian truth. While appearing in polemic as early as the middle of the twelfth century, this imagery manifests itself predominantly in Iberian anti-Jewish polemic beginning in the late thirteenth century and continues throughout the fourteenth. Although it emerges precisely at a time when anti-Muslim polemical imagery had become relatively fixed and when the social significance of Islamic civilization in Castile had been complicated after 1248 by the growth of a new minority class of Mudéjar Muslims, I will argue below that the emergence and disappearance of the "rhetorical Muslim" should be measured according to the evolution of the Christian anti-Jewish writing where it appeared more than according to anti-Muslim literature or the vagaries of Christian social engagement with real Muslims. At the same time, by noting the progressive willingness of Christian anti-Jewish writers to associate themselves conceptually with Islamic texts after the middle of the thirteenth century, it will be possible to offer a little-known exception to the standard picture of Christian thinking about Muslims in which, in John Tolan's estimate, "little truly new was written about Islam between 1300 and the Enlightenment". ${ }^{11}$

\section{From Infidel to Witness}

In order to appreciate the shift in the polemical use of Muslims in anti-Jewish arguments beginning in the later thirteenth century, it is necessary to understand the uncertainty over Islam's place relative to Judaism that predominated before 1200. At the opening of the twelfth century, Muslim belief is represented in Petrus Alfonsi's Dialogus contra Iudaeos (Dialogue Against the Jews) as being more-or-less equal

${ }^{10}$ On the Hermeneutical Jew, see Cohen, Living Letters, p. 3 n. 3; Dahan, Les intellectuels, p. 585; and Markus, "The Jew".

11 Tolan, Saracens, p. 276. 
to Jewish infidelity. As the first Latin Christian work to discuss the Talmud and the Qur'ân together, the Dialogus was both among the most popular and influential anti-Jewish polemics of the Middle Ages and also the principal source of information about Islam in Latin Christendom for nearly two centuries. Although the Jewish voice in the text, Moses, claims in the fifth book that Islamic "law is generous $(\operatorname{larg} a) \ldots$ [and] grounded on an unshakable foundation of reason" (super inconvulse fundamentum rationis fundatam) and claims that "God loved [the Muslims]" (Deus eos dilexit), the Christian voice, Peter, affirms that Muhammad was a "liar" (mendacem) who was "deceitful in everything" (in omnibus fallacem) and who "denied Christ" (Christum denegat). ${ }^{12}$ In this way, the text presents Muslim belief as a direct competitor of Christianity, as bad or worse than Judaism. ${ }^{13}$ Similarly, a few decades later, Peter the Venerable of Cluny (d. 1156) showed himself to be almost as fierce an opponent of Muslim belief as Petrus Alfonsi, writing two acerbic anti-Muslim polemics and commissioning the translation into Latin of a host of Arabic texts, including the Qur'ān and alKindī's letter, explicitly for use in anti-Muslim polemical argument. The anonymous annotations written in the margins of Robert of Ketton's Latin Qur'ān translation, a work commissioned by Peter, reveal an explicit hostility over the apparent Christological parallels between the Qur'ān and Christian belief, calling the comments on Jesus "stupid and heretical" (stulta et heretica), and those on the Virgin as "a monstrous and unheard-of fable" (fabulam inauditam et monstruosam) ${ }^{14}$

At the same time, however, despite this condemnation, there is a clear attempt in the writing of Peter and his associates to emphasize a hierarchy of faith in comparing Jews and "Saracens" and to vilify the former in stronger terms than the latter. For example, Peter's collaborator Pedro de Toledo, the translator of the al-Kindi text into Latin, added into his translation this curious remark (often misattributed to Peter himself):

12 Pedro Alfonso, Diálogo, pp. 91 and 103; translated in Dialogue pp. 146-7 and 163, with my changes.

${ }^{13}$ On the fifth book, see Septimus, "Petrus Alfonsi"; Tolan, Petrus Alfonsi, pp. 27-33 and 108-110; Tolan, Saracens, pp. 148-155; and Grant, "Ambivalence".

${ }_{14}$ Paris, BnF MS Arsenal 1162, fols. 32v, 33v, and see also 35v. On the anonymous annotations to Ketton's Qur'ān, see d'Alverny, "Deux traductions", pp. 98-103; Tolan, "Peter of Cluny", p. 54; Tolan, Saracens, p. 156; Burman, Religious Polemic, pp. 84-89; Burman, Reading the Qur'ān, pp. 60-76; Kritzeck, Peter the Venerable, pp. 57-58 n. 31; and Martínez Gázquez, "Las glosas", pp. 141-151. Peter's anti-Muslim writing has been edited in Petrus Venerabilis, Schriften. 
"As the proverb about the Jew goes, a Jew is not quite a Jew until he turns a Saracen. Hardly anyone loves his law except when he has first accepted some other". ${ }^{15}$ In this somewhat convoluted assertion, Muslim belief seems to represent a more faithful version of Jewish belief, even if imposed by force. ${ }^{16}$ Peter himself does mention Muslims in a few key places of his lengthy anti-Jewish polemic, the Adversus Iudaeorum inveteratam duritiem (Against the Inveterate Obduracy of the Jews). ${ }^{17}$ Out of the seven short passages mentioning Islamic belief, Muslims, or Muhammad in this text, two in particular stand out in contrast to the antiMuslim remarks of Petrus Alfonsi. Peter first introduces the language of testimony when he affirms that Muslims "are witnesses", although he then adds critically that "[the Muslim is] a witness and a teacher of his own error" (testes sunt ipsi, testis et erroris ipsius magister). ${ }^{18}$ Rather than simply condemning Muslims together with Jews as Petrus Alfonsi does, Peter also refers to Muslims as "witnesses" (testes) who testify to the truth Christian arguments alongside other "heathens" (ethnicos). Peter invokes this Muslim "testimony" as a tool in his argument against the Jews. Speaking about the miracle of the Holy Fire, which Christians believed would appear at the sepulcher of Jesus on every Holy Saturday, Peter argues to an imagined Jewish reader, "You will not be able to say that Christians fabricated this, since it has as witnesses these heathens and Saracens...if you shall deny, Jew, what Christians say about this great miracle, will you be able to deny what all eastern and southern heathens and Saracens confirm to you"? ${ }^{19}$ In making this argument, he signals

15 "Sicut de iudeo proverbium dicit: iudeus nisi postquam efficitur sarracenus iudeus non est, vix aliquis suam legem, nisi prius aliam acceperit, diligat”. See González Muñoz, Exposición, p. 62; and see also Muñoz Sendino, “Al-Kindi, Apologia”, p. 411.

${ }^{16}$ Such an idea was not unique to Pedro, but can also be found in some letters of Peter the Venerable, which state that Jews are "vile blasphemers far worse than any Saracens". See Letters, vol. 1, p. 328; Kritzeck, Peter the Venerable, p. 262 and Cohen, Living Letters, pp. 250-254.

${ }^{17}$ For an analysis of Peter's views of Islam, see Tolan, Saracens, pp. 155-165 and Tolan, "Peter of Cluny". On Peter's views of Judaism and Islam, see Iogna-Prat, Ordonner et exclure, pp. 281-323 and 324-359, respectively.

${ }_{18}$ Peter the Venerable, Adversus Iudaeorum, p. 110, my emphasis. Peter follows this with a citation from "libro suo", i.e. the Qur'ān 3:20, in Ketton's translation.

19 "Non poteris de isto dicere hoc confinxisse Christianos, cum habeat testes ipsos ethnicos et Sarracenos...si negaveris ergo, Iudaee, quod de hoc tanto miraculo fatentur Christiani, nunquid negare poteris, quod inde confirmant totius orientis tibi ac meridiei ethnici ac Sarraceni"? Adversus Iudaeorum, pp. 122-123. Some other sections in the Adversus Iudaeorum that mention Islam are found on pp. 44, 108-111, 122-123, 141, 147, and 184. 
how Islamic texts and ideas might to be invoked as part of Christian arguments against Jews even as Muslims are accused of mistaken belief.

Despite these examples, Muslims appear rarely in explicitly antiJewish writing of the twelfth century and on the whole Muslim texts provide little support for Christian arguments proffered in an antiJewish context. ${ }^{20}$ But the language of "testimony" used sparingly in Peter the Venerable's Adversus Iudaeorum began to reappear with more frequency in some anti-Jewish texts written near or after the middle of the thirteenth century, beginning with the later polemical writing of the Dominican polyglot Ramon Martí (before 1220-after 1284). Martí's two earliest extant works, the Explanatio simboli apostolorum (Explanation of the Apostles' Creed, ca. 1257) and De seta Machometi (On the Sect of Muhammad, ca. 1257), both contain direct polemics against Islam, much of which is based on twelfth-century sources. ${ }^{21} \mathrm{He}$ dedicated the remainder of his career overwhelmingly to anti-Jewish polemic, producing both the Capistrum Iudaeorum (Muzzle for the Jews) in $1267^{22}$ and his longest work, the Pugio fidei (Dagger of Faith) in $1278 .{ }^{23}$ In contrast to the earlier books directed against Islam, both later works include very little anti-Muslim polemic and both invoke Islamic beliefs and religious texts in support of their arguments in proof of Christianity. This is done not to refute Muslim belief, as Martí did in his Explanatio and De seta, but to use the support of Islamic sources to argue against the veracity of Jewish ideas. ${ }^{24}$

${ }^{20}$ For Alan of Lille, in his De fide Catholica (from 1200), Islam does not merit much special attention apart from Judaism, and Muslims themselves are guilty of "Judaizing" in their diet and in their polygamy (ita quodammodo iudaizant). As he affirms in the introduction to the anti-Muslim section of his text, "For refuting [the Muslims], the things that we [already] said against the Jews about Unity and Trinity are sufficient". See d'Alverny, "Alain de Lille", pp. 332 and 343; Patrologia Latina, vol. 210, p. 421 and 427.

${ }^{21}$ March, "Ramon Martí", pp. 443-496; and Hernando, "De Seta Machometi", pp. 9-63.

22 On the Capistrum, see Cohen, Living Letters, pp. 342-358; Cohen, "The Capistrum Iudeorum”, pp. 279-296; and Ragacs, “Mit Zaum”.

${ }^{23}$ The Pugio is most widely available in the Leipzig, 1687, edition (facsimile reprint, Farnborough, 1967), itself a reprint of an earlier edition (Paris, 1651). As Merchavia, "The Hebrew Version", pp. 283-288, points out, the earliest and most complete manuscript, Paris, Bibliothèque Sainte-Geneviève, MS 1405, must be consulted for an accurate picture of the original text. All citations here will give the folio in this manuscript first, followed by the page number in the Leipzig edition. For a list of all manuscripts and editions, see Szpiech, "Citas árabes", which also summarizes relevant bibliography.

${ }^{24}$ For passages in Martí's earlier work in which he invoked the support of Islamic texts, see March, "Ramon Martí", p. 454 ("testatus est Machometus"); Hernando, "De Seta", pp. 52-62, especially 54-56. 
The treatment of Islam in the Capistrum and the Pugio is very similar, and many of the arguments given in the former are in fact repeated in the latter. In both texts, Islamic sources are presented as a support for Christian arguments against the Jews. In the Capistrum, Martí begins this argument by first making it clear that Islam is in no way superior to or equal to Christianity, claiming that Muhammad "promised sensual pleasures" (sensibilium voluptatum) and falsely "seduced" (fraudulenter illexit) contemporary Arabs and many others. He likewise insists that heretics, Saracens, and Jews will not be allowed into paradise. ${ }^{25}$ At the same time, however, he affirms that, "every Saracen acknowledges belief in the Lord Jesus, even though he denies it in his actions...In fact, they [the Muslims] do not seem like anything except Christian heretics". ${ }^{26}$ With statements like these, Martí begins in his Capistrum to invoke Muslim texts to support Christian ideas without ever affirming Islamic faith to be true. In the face of this use of Muslim arguments, Jews are excluded from the "majority" opinion of Muslims and Christians and are implicitly represented as both mistaken in their beliefs and forsaken by God.

In his first anti-Jewish work, Martí invokes Muslim sources not only to support Christian ideas. He also directly compares Jews and "Saracens", asserting that even in their erroneous practices, Muslims are still not as corrupt as Jews. At the very end of the Capistrum, in a passage attacking the custom of mezizah be-peh (oral suction of the circumcision wound by a mohel), he compares Jewish and Muslims circumcision practices, exclaiming: "Abraham did not do this. Moses did not command this. God did not order this...The Saracens circumcise themselves and they never do this most abominable thing". ${ }^{27}$ In his discussion of Christian miracles, Martí is driven to concede that Muslims are not only innocent of such practices, but are actually a source of support for Christian truth before the Jews: "About all of these [points] our enemies, that is the Saracens, are judges, as is clear in their own

${ }_{25}$ Capistrum, 1.7.22, vol. 1, p. 298. Cf. Pugio 2.8.13, Bibliothèque Sainte-Geneviève, MS 1405, fol. 67r, p. 368. On paradise, see Capistrum, 1.3.27, vol. 1, p. 126.

26 "Omnis Sarracenus confitetur se credere in Dominum Iesum, et si operibus neget... Nihil ergo aliud videntur quam Christiani haeretici". Capistrum, 1.6.12, vol. 1, p. 258. See also 1.3 .7 , vol. 1 , p. 108 , and 2.2 .9 , vol. 2 , p. 86 .

27 Capistrum, 2.7.33, vol. 2, pp. 286-88. 
confession and in their books". ${ }^{28}$ This status not only as "judges" but also as "witnesses" is framed as an explicit argument in favor of Christianity that "not even the Jews" can deny: "Our enemies, that is the Saracens, are witnesses that...the Lord Jesus did these and many similar things...So many manifest miracles were done by Christ so often that not only can they not be denied by the Saracens, but truly not by the Jews either". ${ }^{29}$

Martí repeats these arguments in the Pugio fidei, where despite his stated intention to argue "principally against the Jews, and secondly against the Saracens", he includes relatively little discussion of Muslims. ${ }^{30}$ Rather than attacking Islamic beliefs, he devotes the first book of the Pugio to proving, on the basis of Islamic and Christian philosophers as well as Aristotle, theorems such as that "God exists" (chapter 2 ), that "pleasure of the flesh is not the highest good" (chapter 3), or that the "world is not eternal" (chapter 12) - philosophical arguments that lack any direct attack on Islam and that have been compared to the arguments of Thomas Aquinas' Summa contra gentiles, which indeed may have been one of Martí's sources. ${ }^{31}$ He likewise includes dozens of citations drawn from Muslim philosophers such as Ibn Sinnā, Ibn Rushd, al-Ghazālī, and al-Fārābīi ${ }^{32}$ The implication of this discussion, even though he does not treat Islamic religion in any detail, is that the

28 "De omnibus his etiam inimici nostri, id est Sarraceni, sunt iudices, ut patet per confessionem ipsorum, et in eorum libris". Capistrum, 1.7.19, vol. 1, p. 294.

29 "Inimici autem nostri, hoc est Sarraceni, sunt testes tamquam illi, quibus constat per crebram famam Dominum Iesum haec et multa alia his similia fecisse...Tot quippe, totiens et tam manifesta miracula a Christo facta sunt, quod non solum a Sarracenis, verum etiam ab ipsis Iudaeis negare [negari] non poterunt”. Capistrum, 1.7.12, vol. 1, p. 282.

${ }^{30}$ Ms 1405 , fol. 2v, Pugio, p. 2. Among the examples of insults or attacks on Islam is one passage citing Muhammad's carnal lust "fraudulently" leading many astray (SainteGeneviève, Ms 1405, fol. 67r, Pugio, p. 368), another in which he calls Muhammad "Hypocrita simul, et scelerosus et haereticus pessimus" (fol. 115r, p. 461), or speaks of "fatuitas Sarracenica" (fol. 259r, p. 718), and another invoking the Qur'ān itself as witness (teste Alcorano) that Muhammad performed no miracles (fol. 67r, p. 368). See also fols. $87 \mathrm{r}$ and 136 r, pp. 411 and 506.

${ }_{31}$ Rodríguez Bachiller, Influencia de la filosofia árabe, pp. 17-18, makes the case that 21 of the 26 chapters in the first part of the Pugio were based on Thomas. On this debate, see Robles, "En torno a una vieja polémica"; Hasselhoff, "Self-Definition" and Wiersma, "Aquinas' Theory".

32 On Martí's Arabic sources, see Cortabarría, "Les sources"; Cortabarría, "La connaissance"; Cortabarría, "Los textos"; Cortabarría, "Las fuentes"; Cortabarría, "Avicenne"; Hasselhoff, "Some Remarks"; on Martí's other sources, see Bobichon, "La 'bibliothèque' de Raymond Martin". 
rational proofs drawn from Muslim philosophers naturally point to the veracity of Christianity, and as such his philosophical pre-polemic serves as an appropriation of Islamic tradition in service of Christian truth. As John Tolan explains, "If many of the most acute philosophical minds of the Middle Ages belonged to Saracens, they must be somehow crypto-Christians, or they must at least secretly reject the law of Muhammad. Like his contemporary Roger Bacon, Martí plays up intellectual division among Muslim thinkers to make Avicenna and alFārābī into free-thinking rationalists who rejected the Koran". ${ }^{33}$

The only direct references to the Qur'ān in the Pugio are, in fact, not found in the first part, the part ostensibly against "Saracens", but in the second and third parts, parts dedicated to the attack on Jewish belief through the proof of Christian ideas about the Messiah, the Trinity, the Virgin Birth and of other notions based on biblical and postbiblical Hebrew and Aramaic sources. In both parts two and three, the Qur'ān is not directly criticized, but is invoked as a witness to the truth of Christian doctrine. In the second, Martí invokes the "testimony" of the Qur'ān as support of the miracles of Jesus, of the Virgin birth, and of the ascension of Jesus to heaven. About these points, he states, "Let those who doubt this ask the Saracens and they will confirm with their own testimony that I speak truly". ${ }^{34}$ In this way, he implies that even though the Qur'ān is not divinely inspired, it still contains, like the postbiblical Hebrew sources treated exhaustively in the text, a testament to the truth of Christian beliefs.

The shift represented by Martís thinking is nowhere more evident than in his citation of the original Arabic text of the Qur'ān and hadìth in the third part of the Pugio. While the citations in the second part of the text are given, in the midst of Arabic philosophical sources, in Latin translation only, the citations of the Qur'ān in the third part-in a discussion that stresses their status as Scripture - are given, together with a handful of passages of Arabic hadith, in Arabic as well as Latin. Apart from one Judeo-Arabic quote from the Dalälat al-hă'irìn (Guide for the Perplexed) by Maimonides (d. 1204), these are the only citations in the whole text that are given in both Arabic and in Latin translation.

33 Tolan, Saracens, p. 241. See also his "Saracen Philosophers".

34 "Interrogent qui de hoc dubitant Sarracenos, et ipsorum testimonio me verum dicere comprobabunt". Pugio fidei, 2.8.11, Bibliothèque Sainte-Geneviève, MS 1405, fol. 65v, Pugio, p. 365. 
Their presentation resembles the style of the abundant Hebrew (and Aramaic) citations in which the original texts are presented on the right side of the folio, and the Latin translations on the left. Most striking of all is the fact that these Arabic citations are written not in Arabic script but in Hebrew characters. ${ }^{35}$ These quotations, which can be found in all of the manuscripts that contain Hebrew text and in both seventeenthcentury printed editions, represent not only the earliest known citations of the Qur'ān in Arabic written in Hebrew characters in a Western Christian manuscript. ${ }^{36}$ More importantly, they also provide an illuminating example of Marti's philosophy of language in the context of his polemical project, in which he cited his sources with increasing precision and completeness in an attempt to approximate his understanding of their "authentic" meaning. In addition by marshalling these Arabic authorities against Jews, he chose to give them not in the form ostensibly most "authentic" to Muslims - in Arabic characters - but instead in a form in which he seems to think an Arabic-speaking Jew might be imagined to approach the Qur'ān -i.e. in Hebrew characters with Tiberian vocalization. ${ }^{37}$ In this case, the use of a script comes to provide the means by which a whole Scripture is usurped. In this newly conceived theological role, the alphabet itself begins to replace the figure of the "rhetorical Muslim" as a theological witness to the historical triumph of Christianity. Martí openly admits the importance of language for his project when he states in the opening to the Capistrum that, "It will be best if this treatise [be written] not only in Latin, but also in Hebrew, and that one have the knowledge of reading Hebrew [aloud], even if he cannot understand it". ${ }^{38}$

In expressing this view and offering these citations, Martí implicitly maintains that his use of the Muslim authorities from the Qur'ān and

35 The Judeo-Arabic citation from Maimonides is found in 3.2.5, on MS 1405, fol. 165r, Pugio, p. 565.

36 On manuscripts of the Pugio, along with an edition of the Arabic and Latin texts of the Qur'ān citations, see Szpiech, "Citas árabes", pp. 76-8, 94-104. One example of the Qur'ānic text being given in a Christian manuscript in Hebrew characters can be found in Vatican City, Biblioteca Apostolica Vaticana, MS Ebr. 357, fols. 51r-156v. See Piemontese, "Il Corano latino", pp. 264-272; and Paudice, "On Three Extant Sources", pp. 227-229.

37 On Jewish copying of the Qur'ān in Hebrew characters, see Lazarus-Yafeh, "Jewish Knowledge", pp. 37-47, in English in Intertwined Worlds, pp. 87-89.

38 "Optimum erit si istud opusculum non solum in Latino, sed etiam in Hebraeo, et scientia legendi, etsi non intelligendi Hebraicum habeatur". Capistrum, 1.1.4, vol. 1, p. 56. On the role of oral reading and on Martís philosophy of languages more generally, see Szpiech, “Translation”, pp. 182-183. 
hadith in Arabic written in Hebrew characters represents the fullest linguistic expression of his notion that authoritative Muslim texts can be invoked as testimony for the Jews of Christian truth. He thus cites "those things that, in the Qur'ān, Muhammad said that God said to him through Gabriel about the Virgin Mary, Mother of God" ${ }^{39}$ His actual argument about Mary in the Qur'ān represents nothing new, having been a part of anti-Muslim polemic at least as far back as the Arabic text of al-Kindī. ${ }^{40}$ Rather, what is significant about Martí's discussion of the Muslim belief in Mary and Jesus is that these arguments, some of which can also be found in Martí's De Seta Machometi in a more polemical context, have been stripped of the majority of their anti-Muslim polemical content and are presented in the context of constructing an argument against Judaism. His citation from "authentic books of the Saracens" (libris autenticis apud sarracenos) shows less concern with refuting Muslim arguments than with manipulating and exploiting them as prooftexts for Christianity. ${ }^{41}$ Such use is, of course, not an example of real approval, but of the strategic invocation of the symbolic support of Islamic sources for Christian purposes.

The perspective evident in Martís anti-Jewish polemic reflects an important shift of the symbolic currency of Islamic civilization within Christian thought in the post-reconquista context of the late thirteenthcentury. It shows that apart from the preoccupation with Muslims as polemical enemies, Christian writers could invoke, within an anti-Jewish context, their rhetorical function-enemies or not-as "witnesses" to Christian belief. In contrast to Martí, who focused the lion's share of his attention on Jewish texts, the polemicists around the turn of the fourteenth century who focus predominantly or exclusively on anti-Muslim polemic such as Riccoldo da Monte Croce or Ramon Llull (d. 1315) do not share Martí's language or perspective on Muslims as allies in the Christian argument against the Jews. Although Monte Croce does make statements in his anti-Muslim literature describing Muslims as "witnesses", affirms that, "never is there such a valid wit-

39 "Ea quae mahometus dixit in alqorano deum dixisse sibi mediante gabriele de beata maria uirgine matre xristi”. Ste-Geneviève MS 1405, fol. 281v, and cf. Pugio, p. 750.

${ }^{40}$ For similar passages from the al-Kindī text, see González Muñoz, Exposición, pp. 123-125. 24-26.

${ }^{41}$ Fol. 282r; p. 750. For his earlier citation of Qur'ān 3:42 and 66:12, see De Seta, pp. 
ness...as when he who is trying to offend speaks praise", he nevertheless makes little use of this argument in the anti-Jewish section of his Libellus ad nationes orientales. ${ }^{42}$ In a similar way, Llull dedicates only a few select works out of his immense oeuvre to engagement with Judaism, and generally does not separate his polemic against Islam from his other polemical arguments. ${ }^{43}$ Unlike Martí, whose attacks focused increasingly on anti-Jewish writing later in his career, Llull and Monte Croce focused predominantly on Muslims in most of their polemical writing, and had little place for alternative representations outside the framework of their own anti-Muslim arguments.

\section{"Moors are Christians"}

The new image of Muslims represented by Martí in his Capistrum and Pugio is even more evident in the Christian anti-Jewish polemics written in the fourteenth century. The first unmistakable example is found in the abundant polemical writing of the Castilian convert from Judaism Abner de Burgos (ca. 1270-ca. 1347). Born sometime in the wake of the Barcelona disputation of 1263, Abner was known after his conversion to Christianity around 1320 as Alfonso de Valladolid. In many ways, Abner/Alfonso's writing marks the culmination of the polemical movement represented by writers like Martí and Llull that centered on the importance of authenticity and language. ${ }^{44}$ Following his conversion, Abner/Alfonso composed numerous anti-Jewish

42 "Scimus quod nunquam est tam validum et robustum testimonium doctrine vel vite quam cum ille laudanda loquitur qui ingerere crimen conatur". See Mérigoux, "Contra legem", p. 136. On this passage, taken nearly verbatim from Gregory the Great's Moralia in Iob, 5.14, see Daniel, Islam, p. 197. See also his comments in 15.2 and 15.5, pp. 127 and 132, respectively. Of Monte Croce's two statements about Islam in the anti-Jewish section of his Libellus, only one invokes the alleged support of Islam, putting them on par with the even more execrable Tartars and pagans: "Nam non solum christiani boni sed etiam mali, set et saraceni, qui habent pessimam legem, et tartari et pagani, qui nullam habent legem, omnes dicunt legem christianorum esse sanctissimam". ["Not only good Christians but also bad ones, and Saracens, who have a terrible law, and Tartars and Pagans, who have no law, all of them say that the law of the Christians is very holy".] Florence, BN Conv. Sopp. C. 8. 1173, fol. 240r. The other argument is provided on fol. 241v.

43 On Llull's views of Judaism, see Hames, The Art of Conversion, pp. 83-117.

${ }_{44}$ Despite the many similarities between them, there is no evidence that Abner/Alfonso knew the writings of either figure first hand. See Chazan, "Maestre Alfonso", pp. 83-94, especially 86; and Szpiech, Conversion and Narrative, pp. 143-173. 
polemics in Hebrew, based primarily on post-biblical talmudic and midrashic sources used as textual authorities. In his longest and most important work, the Hebrew dialogue entitled Moreh Zedek (Teacher of Righteousness), which today survives only in a fourteenth-century Castilian translation as Mostrador de justicia, Abner/Alfonso refers to Muslims on numerous occasions and explicitly invokes certain Islamic ideas as support for his Christological arguments. The Mostrador, which takes the form of a dialogue between a Christian and Jew, is dedicated entirely to anti-Jewish polemic, a point all the more salient given its original composition in Hebrew and the author's explicit remarks that "My words and arguments here are not with Christians, but with contrary Jews" (judios contradezidores) ${ }^{45}$ As a result, there is no discussion of Islamic sources in particular that does not form part of the arguments and counter-arguments of the Jewish and Christian interlocutors. Abner/Alfonso wrote no exclusively anti-Muslim polemical treatises, and the appearance of Muslim sources in his texts serves entirely to lend support to his Christian anti-Jewish argument.

Apart from Abner/Alfonso's appeal to Muslim philosophers, which resembles the discussions of earlier writers like Martí, Abner/Alfonso's citation of Islamic sources in his anti-Jewish polemic is unique in a number of ways. Unlike Petrus Alfonsi's text, in which the Jewish Moses actually becomes a mouthpiece for some of the alleged merits of Islamic belief, thus lumping Jews and Muslims together as equally in error, Abner/Alfonso's Jewish character (called the rebelle or "Rebel") criticizes Muslims. He not only attacks their beliefs, but also lambasts their dietary practices, and argues that both Christians and Muslims "will be considered as one and will be lost at the time of the Messiah" (sserán tenidas en uno e perdidas al tienpo del Christo).$^{46}$ In response to this negative depiction of Christians and Muslims by the Jew, the Christian character (called the mostrador or "Teacher") argues that Christians see Jewish belief as worse than the faith of Muslims:

We Christians do not testify that the law of the Jews is better than the law of the Moors in the way you [the Jew] said. Rather, we should say that the law of the Moors

45 Paris, Bibliothèque Nationale de France, MS Esp. 43, fols. 151v-152r. See Alfonso of Valladolid, Mostrador, vol. 2, p. 28. Cf. fol. 40v/ vol. 1, p. 67.

${ }^{46}$ BnF Esp. 43, fol. 65r; Mostrador, vol. 1, p. 117. 
is not as bad as the faith of the Jews. This is because the Moors, according to their law, do not have all the alterations and discord and bad customs that you, the Jews, are said to have. The act of sodomy, which the Moors allow, is not as bad as what the Jews allow, letting the woman [be taken] in that other way that is not customary. ${ }^{47}$

Rather than condemning the Muslims as lustful sodomites, as was normal in many anti-Muslim polemics, Abner/Alfonso inverts this standard polemical image by asserting that Jews are worse than Muslims because the Jews sodomize their wives. ${ }^{48}$ Such candid statements claiming that Islam is close to Christianity and not particularly corrupt can be found in numerous passages throughout Abner/Alfonso's writing. Thus, in his later work, Teshuvot la-Meharef (Response to the Blasphemer), written in response to his former student Isaac Pollegar, perhaps ca. 1340, he argues that Muhammad accepted Jesus but not the Trinity because he "wanted to make a compromise between the edicts of the Jews and the edicts of the Christians and to take an intermediary path between them in order that neither these nor the others would be very far from turning to him". ${ }^{49}$ Rather than rejecting Christianity out of malice or infidelity, Muslims, following Muhammad, seek

47 "E non damos nos, los christianos, testimonio de que la Ley de los judios es mejor que la ley de los moros en la manera que tú dixiste, mas deuemos dezir que la Ley de los moros non es tan mala como la ffe de los judios. Esto es porque non an los moros, segunt ssu Ley, todas aquellas mudaçiones e desconcordias e malas costunbres que sson dichas de uos, los judios. E con que ya es prouado que aun aquella obra sodomica que los moros ssueltan non es tan mala cosa como la que ssueltan los judios de la muger por la otra parte como no es huso". BnF Esp. 43, fol. 332v; Mostrador, vol. 2, p. 427.

${ }^{48}$ In the Talmud, "turning the table" (hafikhat ha-shulhan, generally understood as anal intercourse) was seen as permissible within the confines of marriage (e.g. BT Nedarim 20b). In Christian anti-Muslim polemic, homosexual sodomy was traditionally associated with Islam. See, for example, Liber Denudationis, 10.3 (Burman, Religious Polemic, pp. 342-43), pseudo-Pedro Pascual (in Sobre la se(c)ta, pp. 110, 130), Riccoldo da Monte Croce (Liber Peregrinationis, p. 184). On these citations, see Daniel, Islam, pp. 165-67. Cf. Oldradus de Ponte (in Zacour, Jews and Saracens, p. 77) and the late fifteenth-century anti-converso treatise Alborayque: "La sodomía es venida de judíos...de los judíos vino a los moros e de los moros a los malos christianos". See Carpenter, Alborayque, p. 95.

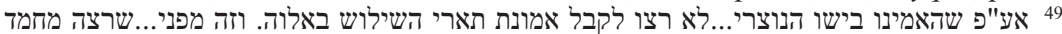

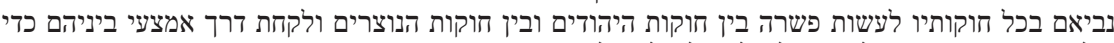

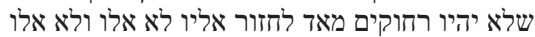

Parma, Biblioteca Palatina, MS 2440, folio 21a, printed in Hecht, "The Polemical Exchange", pp. 365-366 and transl. on 170-171 (missing from the Castilian Teshuvot). Petrus Alfonsi similarly stated that Muhammad "wanted his law to be a mediator between the law of the Christians and that of the Jews" (mediatricem inter Iudeorum et Christianorum legem effici voluit suam) (Pedro Alfonso, Diálogo p. 98: translated in Dialogue, p. 156). 
a "compromise" in order to encourage faith in Jesus. In this middle ground, Islam is seen as closer to Christian truth than Judaism.

Yet Abner/Alfonso does not stop simply by concluding that the Muslims are "not as bad" as the Jews. ${ }^{50} \mathrm{He}$ goes beyond this to affirm that Muslims, in contrast to heretical Jews, "agree with the Christians" on points of doctrine and "believe in Christ in some way". ${ }^{51}$ Even more significantly, he actually argues that Muslims are in many ways, essentially Christians: "All the gentiles of the world, or most of them, accepted the faith of Jesus Christ. Even the Moors accepted it in most things, and they believe that Jesus the Nazarene was the Messiah... All who believe that Jesus the Nazarene was the Christ should be called Nazarenes and Christians. Therefore, we say that the Moors are Nazarenes, which is to say, Christians". ${ }^{52}$ The rhetorical function of this conflation is to represent the Jew as an isolated individual who argues against the "majority" opinion of both Muslims and Christians. The Christian states this explicitly at one point in the text, noting that many commandments should be seen as abrogated by the "new" law of the Messiah. Nearly everyone believes this, we are told. Indeed, "No one denies it except the Jews, who are the fewest of all (los menos de todos) in the world". ${ }^{53}$

${ }^{50}$ We can compare Alfonso's remarks to a popular legal fiction of the thirteenth and fourteenth centuries maintaining that Muslims were "not as bad" as Jews. Such a view can already be found in the Siete Partidas of Alfonso X, on which see Carpenter, "Alfonso el Sabio" and Carpenter, Alfonso X. See Alfonso X's similar remarks in his other works, such as General Estoria, 1.4.6, vol. 1, p. 160; and Cantigas, vol. 2, pp. 250-251. On the Cantigas, see Bagby, "Alfonso X”, pp. 578-583. For a different interpretation of these texts, see Zorgati, Pluralism, p. 42. Alfonso's texts can be compared to those of jurist Oldradus de Ponte (d. after 1337), who argued, in a consilium on whether or not a Jew who converted to Islam ought to be punished under Christian law, that "the sect of the Saracens is not as bad than that of the Jews...One ought not be punished, therefore, for choosing the path of lesser evil". ("Cum secta Sarracenorum sit minus mala quam Iudeorum...non est ergo puniendus qui viam minus malam elegit".) See Zacour, Jews and Saracens, p. 77; Nirenberg, Communities of Violence, pp. 190-195. Cf. the ideas of Hugh of Pisa (d. 1210) in Pakter, Medieval Canon Law, pp. 279-80.

${ }_{51}$ BnF Esp. 43, fols. 153r and 338v; Mostrador, vol. 2, pp. 31 and 438.

52 "Todas la gentes del mundo, o las más dellas, rresçibieron la ffe de Jhesu Christo. E aun los moros la rrescibieron en las más de sus cosas, e creen que Jhesu Nazareno fue el Christo que avia a vinir para dar salvacion al mundo...E todo qui cree de Jhesu Nazareno que fue el Christo conviene de sser llamado 'nazareno' e 'Christiano'. E por ende dezimos que los moros son nazarenos, que quier dezir christianos". BnF MS Esp. 43, fol. 233r; vol. 2, p. 203.

${ }_{53}$ Mostrador, fol. 39v; vol. 1, p. 66. These statements can be compared to the fourteenth-century Libro de las tres creencias (Book of the Three Faiths), sometimes attributed to Abner/Alfonso, in Madrid, Biblioteca Nacional, MS 9302, fols. 20r and 21r, printed on 
Almost contemporary with Abner/Alfonso's writing was the life of the Dominican polemicist Alfonso Buenhombre of Cuenca, bishop of Marrakech (d. ca. 1353), whose work similarly represents a clear example of the Christian representation of the Muslim as his ally in anti-Jewish polemic. Buenhombre's name is associated with two antiJewish texts, both of which he claimed to have translated from Arabic while in captivity after a "very old book...came by chance into my hands recently" (libellum antiquissimum...nuper casu deuenit ad manus meas).$^{54}$ Without any further evidence of his alleged Arabic originals to substantiate these claims, however, they must be taken as spurious, constituting another example of the familiar topos of the proverbial Arabic text, sometimes "hidden by a Jew", that is finally discovered and brought to light for a Christian readership. ${ }^{55}$ One of Buenhombre's alleged translations was the immensely popular Letter of Rabbi Samuel (Epistola rabbi Samuelis), which took the form of a letter written by a Rabbi known as "Samuel the Moroccan" to another Rabbi, "Isaac of Sijilmasa". It survives in over two-hundred fifty manuscripts, in translations into at least six languages, and in abundant early printed copies. ${ }^{56}$ Attempts to link this text to the twelfth-century polemic Ifhàm al-Yahüd (Silencing the Jews), by Jewish convert to Islam Samaw'al al-Maghribì, have shown the texts to be unrelated and further belies Buenhombre's claims to have translated the text from Arabic..$^{57}$

fiche in Carpenter, Text and Concordance, pp. 20-22. On this text, see Szpiech, "Libro de las tres creencias", pp. 967-973.

${ }^{54}$ For this passage, see also Patrologia Latina, vol. 149, p. 335. On Buenhombre, see Tolan, Saracens, pp. 254-255. Latin citations from the Epistola and the Disputatio Abutalib given here follow the critical edition of Buenhombre's complete works by Antoni Biosca i Bas forthcoming in the Corpus Islamo-Christianum series (translations are my own). Corresponding page references for the Epistola are also given for the defective edition in Migne, Patrologia Latina, and for the Disputatio from the García-Jalón de la Lama and Reinhardt edition. I am very grateful to professor Biosca for providing me with an advance copy of his edition of both works.

55 This topos is evident in the introductions to various translations from the court of Alfonso X of Castile such as the Lapidario, and appeared even three centuries later as a narrative device in Don Quijote. For one French example of a forged Arabic text, see Nirenberg, Communities of Violence, pp. 65-67; and Barber, "Lepers, Jews, and Muslims", pp. 9-10.

${ }^{56}$ See Robles, Escritores dominicos, pp. 120-135, who lists over two hundred manuscript copies. See also Kaeppeli, Scriptores Ordinis Praedicatorum, vol. 1, pp. 48-55 and vol. 4, p. 22; Reinhardt and Santiago-Otero, Biblioteca Bíblica, pp. 55-59; and Marsmann, Die Epistel, pp.189-192.

${ }_{57}$ Steinschneider first suggested the possible link with Ifhàm al-Yahüd in 1877 (Polemische, p. 27, and again in Catalogus, pp. 2443-2447). Comparison of the works, 
The first twenty-five chapters of the Epistola are devoted exclusively to traditional points of Christian anti-Jewish polemic based only on biblical testimonia, nowhere mentioning Islam and nowhere using either Islamic sources or post-biblical Hebrew authorities. In a large number of later manuscripts, however, these anti-Jewish arguments are followed by an additional chapter (sometimes divided into two chapters), copied in part from Buenhombre's later work, Disputatio Abutalib, that offers a few proofs from the Qur'ān to support the claim that Muslims believe in Jesus and Mary. ${ }^{58}$ In this final added chapter, Samuel states that although neither Christians or Jews follow the faith of the Muslims, "nevertheless, it would weaken us [in our argument] and be especially a strengthening of the [position of] Christians, especially unlearned ones if those things that are said by the Saracens about Jesus and Holy Mary, his mother, were adduced against us" ${ }^{59}$ Samuel summarizes Muslim belief in Jesus' miracles and prophecy and Mary's virgin pregnancy, affirming that, "the Qur'ān expressly testifies to this" (hoc expresse testificatur Alcoranus). He also laments, in terms that echo the rhetorical strategy of Abner/Alfonso, that Jews are isolated in their exile because, "We are enemies to all people and the testimony of the majority, that is of the Saracens and of the Christians, of the Qur'ān and of the Gospels, [neither] of which we want to believe, is always against us". ${ }^{60}$ References to Muslims both enhance the authenticity of Buenhombre's text as a "libellum antiquissimum" and also strengthen the Christian cause by sheer dint of numbers, being another voice opposed to the Jews and showing them to be the odd men out in the history of revelation and abrogation.

This final chapter of the Epistola, however, would appear in altered form in letter four of Alfonso's slightly later polemic, the Disputatio

however, shows that they have nothing in common beyond the similarity of the author's names. See also Perlmann's remarks in Samaw'al al-Maghribī, Ifhàm, p. 25; Limor, "The Epistle", pp. 184-185; and Biosca i Bas, "Disputatio Abutalib", p. XVIII.

${ }_{58}$ On the extra chapters, see Meersseman, "La Chronologie", pp. 86-89; Hernández, "Alphonse Buenhombre"; Hernández, "El arabista"; Marsmann, Die Epistel, pp. 192-194 and p. 432 note a; and Biosca i Bas, "Disputatio Abutalib", p. XVIII.

59 "...Tamen ad fatigationem nostram esset et ad fortificationem Christianorum, maxime simplicium, si nobis opponerentur illa que dicuntur a Sarracenis de Ihesu et de Maria, matre eius". Opera Omnia. See also Patrologia Latina, vol. 149, p. 365, and the similar remarks on p. 367.

60 "Sumus inimici super omnes gentes, et nihil proficimus. Et testimonium multorum stat contra nos, scilicet Sarracenorum et Christianorum, et Alcoranus et Euangelium, quibus nolumus credere". Opera Omnia. See also Patrologia Latina, vol. 149, p. 366. 
Abutalib sarraceni et Samuelis iudei (Dispute of Abu Talib the Saracen with Samuel the Jew). This text takes the same form, that of a set of letters between two friends, one Muslim and the other Jewish (again named Samuel) ${ }^{61}$ In Buenhombre's prologue to his alleged translation-in language that is nearly identical to his prologue to the Epistola - he claims "not to have changed a thing" from the original Arabic text, noting that the Arabic text will candidly reveal Muslim secrets. ${ }^{62}$ The text is premised on the joint agreement by Muslim and Jew to use only the textual authorities of their opponent. The Muslim Abu Talib argues in favor of Christianity through the Bible and a small handful of allusions to rabbinical texts while Samuel the Jew, on the other hand, argues in favor of Christianity through the Qur'àn. ${ }^{63}$ As Abu Talib explicitly says in the fifth letter, "I do not intend to adhere to your proofs or my own for myself, but only to prove by your scriptures what you had tried to disclose to me by my scriptures". ${ }^{64}$

Just as in the Epistola, there is generally little innovation in argument or breadth of sources to distinguish Buenhombre's writing from the centuries of earlier medieval anti-Jewish writing based on biblical testimonia. Abu Talib cites nothing from the Talmud and refers in passing to only a handful of Rabbinical notions and texts. ${ }^{65}$ Virtually all of his citations are derived second-hand from earlier writers such as Rodrigo Jiménez de Rada (ca. 1170-1247), Lucas of Tuy (d. 1249), and his older contemporary Nicholas of Lyra (ca. 1270-ca. 1349). ${ }^{66}$ What is original to this text is not the actual body of authorities used in argument, but the narrative framing of the polemic, a frame within which standard proChristian auctoritates are cited by a non-Christian interlocutor even

${ }^{61}$ Opera Omnia. Cf. La disputa de Abutalib, p. 59. A full study can be found in Biosca i Bas, "Disputatio Abutalib", pp. I-LXXVII.

${ }^{62}$ Opera Omnia. See also La disputa de Abutalib, p. 45; Patrologia Latina, vol. 149, p. 335.

${ }_{63}$ Opera Omnia; La disputa de Abutalib, pp. 55 and 61.

64 "Non tamen tuis probationibus nec meis in ista parte intendo adherere pro me nec meis, sed solum per scripturas tuas tibi probabiliter ostendere, quod conatus fuisti per meas scripturas et michi reserare". Opera Omnia. Cf. La disputa de Abutalib, p. 103. On his citations of the Qur'ān in Latin, see Biosca i Bas, "Las traducciones" and Biosca i Bas, "Rasgos islámicos”, pp. 95-102.

${ }^{65}$ For example, Abu Talib mentions "glosa uestra" (La disputa de Abutalib, p. 95), names the book of Judges from the Mishneh Torah of Maimonides (p. 101), and paraphrases Bereshit Rabbah, which he calls simply "Glosa nostra" (p. 121).

${ }^{66}$ For an evaluation of his sources, see Biosca i Bas, "Disputatio Abutalib", pp. IXXVIII. 
though a Christian character and voice are totally absent from the story. In this innovative use of non-Christian characters, we see the full flowering of the rhetorical device of invoking the polemical opponent as a mouthpiece for the Christian polemical cause. Although both are involved in the conversion of the other, it is the Muslm Abu Talib who serves as the central vehicle of conversion, for it is he who first converts Samuel the Jew, leading his Jewish friend to concede in his final letter, "I am no longer blinded by the cloud of ignorance...I confess I have received this from you...". ${ }^{67}$ Abu Talib's role as the converter of Samuel, however, affects him as well and he also converts to Christianity at the end of the text. He claims that his conversion is based not merely on the proofs given by Samuel, but also through reconsideration of his own knowledge of what he calls the "secret" Christian beliefs of Muslims. ${ }^{68}$

In the "very old" Arabic original purportedly translated by Buenhombre, and indeed in the very character of Abu Talib, this Muslim who converts the Jew to Christianity and is then converted by his own authorities, we see what John Tolan calls a "Dominican missionary's dream". ${ }^{69}$ Buenhombre's fake translation, the ultimate trope of feigned authenticity, is parallel to Abu Talib's conversion, and both dramatize the discovery of the kernel of Christianity even within the authoritative texts of non-Christians. By presenting both an imagined Arabic original text and an imaged Arab whose conversion that text allegedly recounts, Buenhombre's work constitutes the ultimate adoption of the topos of the "rhetorical Muslim" as a tool for persuasion of the Jew.

The legacy of Ramon Martís symbolic use of Islamic sources in his anti-Jewish writing can be traced through the fourteenth century even beyond the Iberian Peninsula. ${ }^{70}$ In the writing of fourteenth-cen-

\footnotetext{
67 "Iam ignorantie nubilo obcecari minime ualeo...hoc me a te fateor accepisse...". Opera Omnia. See also La disputa de Abutalib, pp. 131-133. In his final letter, Abu Talib supports his friend's decision to convert (p. 139).

${ }^{68} \mathrm{He}$ concludes that, "Tue enim legis testimonia et nostre legis inconuenientia me ultimate compellunt et errorem relinquere et Christianitatis nomen predicare". ["The testimonies of your law and the contradictions of our law finally compel me to relinquish error and to preach the name of Christianity".] Opera Omnia. See also La disputa de Abutalib, p. 140.

${ }^{69}$ Tolan, Saracens, p. 255.

${ }^{70}$ Nevertheless, there are various contemporary writers outside the Iberian peninsula who do not make any references to Muslims in their statements on Judaism, such as Simeon Simon (d. after 1324), Petrus de Pennis (fl. 1330-1342), Guido Terreni (d. 1342), and Richard Fitzralph (d. 1360). For a general discussion of these writers, see Daniel, Islam, pp. 197-199.
} 
tury Franciscan exegete Nicholas of Lyra, for example, "Saracens" are depicted as a pernicious force in the world, and in his Postilla commentary on the biblical book of Revelation, Nicholas equates them with the Antichrist. ${ }^{71}$ Nevertheless, in his Postilla on Isaiah 8:2, Lyra, who seems to have obtained most of his information about Islamic sources from Vincent of Beauvais' reworking of the Dialogus of Petrus Alfonsi, also copies (in order) the same Qur'ānic citations about Mary given by Martí. He echoes Martí directly, stating, "not only is [Mary] called blessed by Christians, but also by Saracens, as it is in the Qur'ān of Muhammad, 'And the Angels said, O Mary..."', etc..$^{72}$ Even more significantly, even though Lyra says nothing about Muslims in his earlier anti-Jewish treatise Quodlibetum de adventu Christi (Quodlibet on the Coming of Christ), written around 1309, he does include comments similar to those given in his exegesis in his anti-Jewish Responsio ad quemdam Iudaeum (Response to a Certain Jew, also called the Tractatulus), written in 1334 in response to book eleven of the Sefer Milhamot Hashem (Book of the Wars of the Lord) by twelfth-century polemicist Jacob ben Reuben. There, Lyra cites not only Qur'ān 3:42 and 45, but also includes the exact hadith citations given in Arabic (in Hebrew characters) in the Pugio fidei. ${ }^{73}$ Such use of Marti's representation of Islamic sources shows the very gradual spread of this image beyond the Iberian Peninsula throughout the first half of the fourteenth century.

The influence of Martí's ideas is harder to find in the later part of the century, and in polemical writing of the early fifteenth century, those anti-Jewish writers who repeat Martí's Qur'ān citations seem to copy them indirectly from Lyra. At the Jewish-Christian Disputation of Tortosa (1413-14), for example, the main Christian representative, convert Gerónimo de Santa Fe (Joshua Halorki before his conversion; d. ca. 1419), does copy Martí's citations of the Qur'ān just as Nicholas of Lyra does, but nevertheless makes little direct use of Islamic sources

${ }^{71}$ Biblia latina cum postillis, vol. 4, pp. 133v-134r. On Lyra's citations, see Krey, "Nicholas of Lyra", pp. 157-158.

${ }^{72}$ Postilla on Isaiah 8:2. Biblia latina, vol. 3, pp. 14v-15r. Lyra's use of Martí had the curious result of incorporating these verses from the Qur'ān into the text of many earlymodern Christian Bibles.

73 The text, which was printed much less than the Quodlibetum, can be found in Biblia sacra cum glossis, vol. 6, pp. 280B-285D. The citations of the Qur'àn and hadith taken from Martí are found on vol. 6. p. 281G. On Lyra's response to Jacob ben Reuben, see Blumenkranz, "Nicolas de Lyra", pp. 47-51; and Levy, "Sefer Milhamot hashem", pp. 270-265. 
in his arguments against his former Jewish community. ${ }^{74}$ His mentor, the convert and Bishop Pablo de Santa María (Solomon Halevi before his conversion around 1390-91; d. 1435), similarly copies the same citations in the same order and argues against Nicholas of Lyra that the "sect of the Saracens" should not be equated with the Antichrist because "even though it is bad and pernicious, it is still not noxious or dangerous to the faithful like other previous sects". ${ }^{75}$ Despite these references, however, Islamic sources appear rarely in Pablo's writing, and he makes no bold assertions such as those found in fourteenthcentury Christian writers. When Muslims are mentioned, it is not in arguments against the Jews. ${ }^{76}$ In the decades after Pablo's death in 1435, attitudes toward Muslims and Islamic sources among Christian writers such as Alfonso de Espina (d. ca. 1491) and Valencian bishop Jaime Pérez de Valencia (d. 1490 or 91) shifted even more noticeably. In their discussion of Islam, these writers more closely resemble twelfth-century polemicists such as Petrus Alfonsi, and Espina in fact copies Alfonsi extensively in virtually every point where he discusses Muslim belief. ${ }^{77}$ The invocation of the Qur'ān in support of Christian truth is for virtually all fifteenth-century anti-Jewish writers, a fossilized polemical topos, occasionally repeated without being altered or elaborated.

${ }^{74}$ For the mention of Muslim belief in Jesus and Mary in the Latin protocol of the Tortosa disputation, see Pacios López, La Disputa de Tortosa, vol. 2, p. 388. In his Contra Iudaeorum perfidiam, he describes Jews and Muslims as both only partly in error: "Et quamis hodie nonnullae Gentes vivant sub aliquibus erroribus, prout sunt Mauri qui afferunt Mahometem fuisse Prophetam, et Iudaei qui per falsam doctrinam Talmut reguntur; attamen, cum hoc, omnes in genere legi Mosaicae fidem perhibent qualemcumque et firmiter credunt a Deo mundum de nihilo creatum". ["Although today not a few nations live under some errors - like the Moors, who adduce that Muhammad was a prophet, and the Jews who are ruled by the false doctrine of the Talmud - nevertheless, despite that, all ascribe faith of whatever kind in its origin to Mosaic law and firmly believe the world was created by God from nothing".] Contra Iudaeorum perfidiam 1.10, vol. 26, p. 541.

75 "Licet mala et pernitiosa, non tamen fidelibus nociva nec periculosa sicut aliae sectae praecedentes". Addition on Apocalypse, 13-14, Biblia latina, vol. 4, p. 337r. On these citations, see Krey, "Nicholas of Lyra", pp. 158-161 and 169 notes 32-33.

${ }^{76}$ Pablo hardly mentions Islam in his anti-Jewish Scrutiny of Scriptures (Scrutinium Scripturarum) from 1432-1434. Significantly, Islam makes no appearance in the first section of the text - the Jewish-Christian debate - but only appears in the second part, after the Jew's conversion. See Scrutinium Scripturarum, p. 384.

${ }^{77}$ I am grateful to José Martínez Gázquez for showing me the extent of Espina's use of Alphonsi. 


\section{Hermeneutical Muslims?}

The consideration of the evolution of Muslim "testimony" in antiJewish polemical writing naturally invites comparison with the traditional Christian image of Jewish "testimony" to Christian truths through disbelief, an image most closely associated with Augustine of Hippo (d. 430). In Augustine's formulation, Jews should be protected in Christian society as a testimonium scripturarum ("a testimony of the Scriptures"), on account of their disbelief in Christian truths found in their own books. ${ }^{78}$ Despite their similarities, however, the invocation of Muslims in anti-Jewish polemic as "witnesses" to Christian truth is in fact very different in one key respect: Whereas Jews are imagined to "testify" by virtue of their alleged "disbelief", Muslims, in the examples cited above, are witnesses by virtue of their actual belief in Mary and Jesus. By the same token, Muslims, in contrast to Jews, fulfill no larger figural cycle of revelation and prophecy in Christian soteriological history: Christians do not believe that any scriptures foretold Muslim infidelity, nor do Christians think that Islam was superseded by Christianity. On the contrary, Muslims play a rhetorical role in Christian polemic only by adding another voice in harmony with Christian belief. This Muslim agreement with Christian truth in anti-Jewish polemical writing serves only to exclude the Jews, casting them, in the words of Alfonso Buenhombre, as "enemies to all people", forever at odds with "the testimony of the majority, that is of the Saracens and of the Christians, of the Qur'àn and of the Gospels".

Considering the historical evolution of this image, appearing in the thirteenth century and more or less disappearing by the middle of the fifteenth, it would be tempting to search for an explanation in the changing political landscape of Castile in the wake of the Christian conquests of the Muslim cities of Córdoba (1236), Valencia (1238), Murcia (1243), Jaén (1245), and finally Seville (1248). It seems at first logical to connect the new polemical representation of Islam to changing political fortunes, attributing the conceptual, theological "domestication" of Islam to its military subjugation. ${ }^{79}$ Similarly, one might explain the

78 Augustine, S. Aureli Augustini, p. 356. Transl. in Cohen, Living Letters, p. 39. For Augustine's views on Judaism, see Fredriksen, Augustine and the Jews.

79 This trend is also roughly contemporary with the Christian use of Muslim mercenary soldiers, or genets, in the Crown of Aragón. On the genets, see Catlos, "Mahomet Abenadalill" and Fancy, "Theologies of Violence". 
waning of this new polemical image in the mid-fifteenth century by linking it to the increased Castilian pressure on the Nasrid kingdom of Granada and the increased Muslim threat presented by the rise of Ottoman control of the Mediterranean and the fall of Constantinople in 1453.

Such explanations, however, would misunderstand the nature of the imagery studied here. On the one hand, it does seem defensible that, as Ana Echevarría has argued about fifteenth-century Christian-Muslim relations, "historical events had an important role in the revival of the polemic genre against Islam", especially in the works of writers such as Juan de Segovia (d. c. 1458), Pedro de la Cavallería (d. c. 14581469) and Juan de Torquemada (d. 1468). ${ }^{80}$ On the other hand, however, the examples of "rhetorical" Muslims testifying to Christian truth should, I have argued, be considered apart from and parallel to the representation of Muslims in anti-Muslim polemic. The phenomenon considered here should not be measured and explained in terms of real Christian-Muslim relations (which do seem, as Echevarría shows, to influence anti-Muslim polemics). Rather, it should be measured primarily according to the genre in which it is found, anti-Jewish writing. In other words, the rhetorical Muslim is more a product of changing relations with Jews and Jewish texts than with Muslims and Islamic texts. The use of Muslims as "witnesses" and Islamic texts as "authorities" corresponds to the parallel usage in anti-Jewish polemic of the later thirteenth and fourteenth centuries in which the Talmud, rabbinical exegesis, and medieval Jewish writing were evoked as "testimonies" of Christian truth. This usage, which emerged in the wake of the Jewish-Christian Disputation of Barcelona in 1263, is most in evidence precisely in the works cited here: the Pugio fidei of Ramon Martí, the Mostrador de justicia of Abner of Burgos/Alfonso of Valladolid, and the polemical writing of Alfonso Buenhombre. The waning of that approach in Christian writing in the second half of the fifteenth century, partly in response to the rise of popular anti-converso sentiment after 1449 , corresponds to a similar waning of appeals to post-biblical Jewish literature in service of Christian truth and a more general shift in the nature of anti-Jewish polemical arguments. ${ }^{81}$

${ }^{80}$ Echevarría, The Fortress of Faith, p. 4.

${ }^{81}$ It is interesting to mention the appearance of the topos of the testifying Muslim in a Jewish anti-Christian text of the first half of the fifteenth century, the Sefer Ahitub ve-Zalmon 
The calculated invocation of Islam within late thirteenth- and fourteenth-century anti-Jewish arguments can be seen, at the very least, as a curious footnote to the accepted historiography of Christian-Muslim relations in the later Middle Ages. More broadly, however, such invocations can also be taken to constitute a clear example of the ways that polemical arguments were rarely composed out of universal, static formulas, but were always strategically deployed according to contemporary exigencies and were regularly adapted according to changing pressures and needs. Such symbolic constellations of what we can call a "rhetoric of difference" in subsequent periods evince the mutability of polemical writing that, just like the real adaptations and adoptions so easily traceable on a microhistorical level of social dynamics, was always subject to the pressures of local context and was constantly evolving through innovation and variance. Yet such lability suggests also that these competitive claims of alliance were not single-minded or blind gestures conveying a simple or unchanging meaning. Put simply, polemical imagery and representations of religious difference meant different things in different contexts and were always in need of being glossed and interpreted, adapted and remade.

It should thus be clear that in none of the "polemical fictions" discussed here do such adapted representations reflect sincere Christian views of "real" Muslims, which remained for most ecclesiastical thinkers, as before, heretical enemies to Christian sovereignty and orthodoxy. Rather, in the intellectual context of the late thirteenth through the early fifteenth centuries, Muslims managed to partly escape from the narrow trammels of anti-Muslim polemic, playing a very different role in the parallel evolution of anti-Jewish writing. Although in the twelfth century, as Pedro de Toledo argued in his anti-Muslim writing, "A Jew is not quite a Jew until he turns a Saracen", the picture was to change markedly in later anti-Jewish writing. In the intellectual climate at the dawn of the fourteenth century, "Saracens" who were not quite Saracens found a temporary niche in the Christian imaginary by performing a symbolic service within anti-Jewish polemical attacks.

(Book of Ahitub and Salman), which tells the story of an island ruled by a queen who holds a Jewish-Christian debate. When a Muslim onlooker finally intervenes to state that he is convinced by the Jewish argumentation, then he and the whole island convert to Judaism, while the Christian hangs himself in disgrace. For an edition and study of the Sefer, see Lara Olmo, "Edición crítica". See also Szpiech, "Converting the Queen”, pp. 203-217. 


\section{Bibliography}

Alfonso Buenhombre [Alphonsus Bonihominis], La disputa de Abutalib, Santiago García-Jalón de la Lama and Klaus Reinhardt (eds.), Madrid, Aben Ezra, 2006.

Alfonso Buenhombre [Alphonsus Bonihominis], Opera Omnia, Antoni Biosca i Bas (ed.), Wiesbaden, Harrassowitz Verlag (forthcoming).

Alfonso of Valladolid/Abner of Burgos, Mostrador de justicia, Walter Mettmann (ed.), Opladen, Westdeutscher Verlag, 1994-1996, 2 vols.

Alfonso X, Cantigas de Santa María, Walter Mettmann (ed.), Madrid, Castalia, 1986-88, 3 vols.

Alfonso X, Espéculo: texto jurídico atribuido al rey de Castilla don Alfonso X, el Sabio, R. MacDonald (ed.), Madison, Hispanic Seminary of Medieval Studies, 1990.

Alfonso X, General Estoria, Pedro Sánchez-Prieto (ed.), Madrid, Biblioteca Castro, 2009, 10 vols.

D’Alverny, Marie-Thérèse, "Alain de Lille et l'Islam. Le 'Contra paganos",, Cahiers de Fanjeaux, 18 (1983), pp. 301-350.

D’Alverny, Marie-Thérèse, "Deux traductions latins du Coran au Moyen-Age", Archives d'histoire doctrinale et littéraire du Moyen Age, 22-23 (1947-48), pp. 69-131.

Augustine of Hippo, S. Aureli Augustini Hipponiensis Episcopi Epistulae, A. Goldbacher (ed.), Vienna, F. Tempsky, 1904, vol. 44, Corpus scriptorum ecclesiasticorum latinorum.

Bagby, Albert, "Alfonso X, el Sabio compara moros y judíos", Romanische Forschungen, 82 (1970), pp. 578-583.

Barber, Malcolm, "Lepers, Jews, and Muslims: The Plot to overthrow Christendom in 1321", History, 66 (1981), pp. 1-17.

Biblia latina cum postillis Nichoae de Lyra et additionibus Pauli Burgensis, Nuremberg, Anton Koberger, 1497, 4 vols.

Biblia sacra cum glossis interlineari, et ordinaria, Nicolai Lyrani postilla, ac mortalibus, Burgensis additionibus, et Thoringi replicis, etc, Venice, [s.n.], 1588,6 vols.

Biosca i Bas, Antoni, "Dispvtatio Abutalib. Edición crítica, traducción y estudio", Ph.D. Diss., Alicante, 2006.

Biosca i Bas, Antoni, "Las traducciones coránicas de Alfonso Buenhombre”, Journal of Medieval Latin, 18 (2008), pp. 257-277.

Biosca i Bas, Antoni, "Rasgos islámicos en la Carta de Samuel", in Miquel Barceló, Pedro Bádenas de la Peña and José Martínez Gázquez (eds.), Musulmanes y cristianos en Hispania durante las conquistas de los siglos XII y XIII, Barcelona, Bellaterra, 2005, pp. 95-102.

Blumenkranz, Bernhard, "Nicolas de Lyra et Jacob ben Ruben", Journal of Jewish Studies, 16 (1965), pp. 47-51. 
Bobichon, Philippe, 'La 'bibliothèque' de Raymond Martin au couvent SainteCatherine de Barcelone: sources antiques et chrétiennes du Pugio fidei (ca. 1278)" (forthcoming).

Burman, Thomas, Reading the Qur'ān in Latin Christendom, 1140-1560, Philadelphia, University of Pennsylvania Press, 2007.

Burman, Thomas, Religious Polemic and the Intellectual History of the Mozarabs, c. 1050-1200, Leiden, Brill, 1994.

Carpenter, Dwayne (ed.), Alborayque, Mérida, Editoria Regional de Extremadura, 2005.

Carpenter, Dwayne, “Alfonso el Sabio y los moros: algunas precisiones legales, históricas y textuales con respecto a Siete Partidas 7.25", Al-Qantara, 7, 1-2 (1986), pp. 229-252.

Carpenter, Dwayne, Alfonso X and the Jews: An Edition of and Commentary on Siete Partidas 7.24, "De los judios", Berkeley, University of California Press, 1986.

Carpenter, Dwayne (ed.), Text and Concordance of Libro de las tres creencias, Biblioteca nacional de Madrid Ms 9302, Madison, Hispanic Seminary of Medieval Studies, 1993.

Catlos, Brian, "Mahomet Abenadalill: A Muslim Mercenary in the Service of the Kings of Aragon (1290-1291)", in Harvey Hames (ed.), Jews, Muslims, and Christians In and Around the Crown of Aragon: Essays in Honour of Elena Lourie, Leiden, Brill, 2004, pp. 257-320.

Chazan, Robert, "Maestre Alfonso of Valladolid and the New Missionizing", Revue des Études Juives, 143 (1984), pp. 83-94.

Cohen, Jeremy, Living Letters of the Law: Ideas of the Jew in Medieval Christianity, Berkeley, University of California Press, 1999.

Cohen, Jeremy, review of Allan Cutler and Helen Cutler The Jew as Ally of the Muslim: Medieval Roots of Anti-Semitism, in Judaism, 37 (1988), pp. 240-242.

Cohen, Jeremy, "The Capistrum Iudeorum of Raymundus Martini" [Hebrew], in Ezra Fleischer et al. (eds.), Me'ah Shearim: Studies in Medieval Jewish Spiritual Life in Memory of Isadore Twersky, Jerusalem, Hebrew University Magnes Press, 2001, pp. 279-296.

Cohen, Jeremy, "The Muslim Connection; or, On the Changing Role of the Jew in High Medieval Theology", in Jeremy Cohen (ed.), From Witness to Witchcraft: Jews and Judaism in Medieval Christian Thought, Wiesbaden, Harrassowitz, 1997, pp. 141-163.

Cortabarría, Ángel, “Avicenne dans le "Pugio Fidei” de Raymond Martin", Mélanges de l'Institut Dominicain d'Études Orientales du Caire, 19 (1989), pp. 9-16.

Cortabarría, Ángel, "La connaissance des textes arabes chez Raymond Martin, O.P. et sa position face de l'islam", Cahiers de Fanjeaux, 18 (1983), pp. 279-300.

Cortabarría, Ángel, "Las fuentes árabes del 'Pugio Fidei' de Raimundo Martí: Algazel (1085-1111)”, Ciencia Tomista, 112 (1985), pp. 581-596. 
Cortabarría, Ángel, "Les sources arabes de 1' 'Explanatio Symboli' du Dominicain catalan Raymond Martin”, Mélanges de l'Institut Dominicain d'Études Orientales, 16 (1983), pp. 95-116.

Cortabarría, Ángel, "Los textos árabes de Averroes en el 'Pugio Fidei' del dominico catalán Raimundo Martín”, in Actas del XII Congreso de la U.E.A.I, Málaga, 1984, Madrid, Unión Européenne d'Arabisants et d'Islamisants, 1986, pp. 185-204.

Cutler, Allen and Cutler, Helen, The Jew as Ally of the Muslim: Medieval Roots of Anti-Semitism, Notre Dame, University of Notre Dame Press, 1986.

Dahan, Gilbert, Les intellectuels chrétiens et les juifs au moyen âge, Paris, Cerf, 1990.

Daniel, Norman, Islam and the West: The Making of an Image, rev. ed., Oxford, Oneworld, 1993.

Dondaine, A., "Ricoldiana. Notes sur les oeuvres de Ricoldo da Montecroce", Archivum Fratrum Praedicatorum, 37 (1967), pp. 119-179.

Echevarría, Ana, The Fortress of Faith: The Attitude Towards Muslims in Fifteenth Century Spain, Leiden, Brill, 1999.

Fancy, Hussein, "Theologies of Violence: The Recruitment of Muslim Soldiers by the Crown of Aragon", Past \& Present, (2013) (forthcoming).

Fredriksen, Paula, Augustine and the Jews. A Christian Defense of Jews and Judaism, New York, Doubleday, 2008.

González Muñoz, Fernando, Exposición y refutación del Islam: La versión latina de las epístolas de al-Hāšimì y al-Kind̄̄, La Coruña, Universidade da Coruña, 2005.

Grant, Barbara, "Ambivalence in Medieval Religious Polemic: The Influence of Multiculturalism on the Dialogues of Petrus Alphonsi", in Ross Brann and David Owen (eds.), Languages of Power in Islamic Spain, Bethesda, MD, CDL Press, 1997, pp. 156-177.

Griffith, Sidney, "Jews and Muslims in Christian Syriac and Arabic Texts of the Ninth Century", Jewish History, 3 (1988), pp. 65-94.

Griffith, Sidney, The Church in the Shadow of the Mosque. Christians and Muslims in the World of Islam, Princeton, Princeton University Press, 2008.

Hames, Harvey, The Art of Conversion. Christianity and Kabbalah in the Thirteenth Century, Leiden, Brill, 2000.

Hasselhoff, Görge, "Self-Definition, Apology, and the Jew Moses Maimonides: Thomas Aquinas, Raymundus Martini, Meister Eckhart, Nicholas of Lyra", in Yossef Schwartz and Volkhard Krech (eds.), Religious Apologetics-Philosophical Argumentation, Tübingen, Mohr Siebeck, 2004, pp. 285-316.

Hasselhoff, Görge, "Some Remarks on Raymond Martini's (c. 1215/30-c. 1284/85) Use of Maimonides", Trumah, 12 (2002), pp. 133-148.

Hecht, Jonathan, "The Polemical Exchange between Isaac Pollegar and Abner of Burgos/Alfonso of Valladolid according to Parma MS 2440. Iggeret Teshuvat 
Apikoros and Teshuvot la-Meharef', Ph.D. Diss., New York, New York University, 1993.

Hernández Martín, Ramón, “Alphonse Buenhombre et son manuscrit conservé à l'Archivum Generale Ordinis Praedicatorum (AGOP)", Mémoire Dominicaine, 15 (2001), pp. 37-54.

Hernández Martín, Ramón, "El arabista medieval Alfonso Buenhombre”, Anámnesis, 21 (2001), pp. 105-136.

Hernando, J., "De Seta Machometi o de Origine, Progressu et Fine Machometi et Quadruplici Reprobatione Prophetiae Eius", Acta Historica et Archaeologica Mediaevalia, 4 (1983), pp. 9-63.

Iogna-Prat, Dominique, Ordonner et exclure. Cluny et la société chrétienne face à l'hérésie, au judaïsme, (1000-1150) et à l'islam 1000-1150, Paris, Aubier, 1998.

Jerónimo de Santa Fe, Contra Iudaeorum perfidiam, in Maxima bibliotheca veterum patrum et antiquorum scriptorum ecclesiasticorum, Lyon, Anissonios, 1677, 27 vols., vol. 26, pp. 528-554.

Kaeppeli, T., Scriptores Ordinis Praedicatorum Medii Aevi, Rome, S. Sabinae, 1980,4 vols.

Kedar, Benjamin, Crusade and Mission. European Approaches toward the Muslims, Princeton, Princeton University Press, 1984.

Kedar, Benjamin, "De iudeis et sarracenis: On the Categorization of Muslims in Medieval Canon Law", in R.I. Castillo (ed.), Studia in honorem eminentissimi cardinalis Alphonsi M. Stickler, Rome, LAS, 1992, pp. 207-213, reprinted in The Franks in the Levant, $11^{\text {th }}$ to $14^{\text {th }}$ Centuries, Aldershot, Variorum, 1993, XIII, pp. 207-213.

Krey, Philip, "Nicholas of Lyra and Paul of Burgos on Islam", in John Tolan (ed.), Medieval Christian Perceptions of Islam, London, Routledge, 1996, pp. 153-174.

Kritzeck, James, Peter the Venerable and Islam, Princeton, Princeton University Press, 1964.

Lara Olmo, J.C., "Edición crítica, traducción y comentario de la obra Sefer 'Ahitub we-Salmon", Ph.D. Diss., Madrid, Universidad Complutense, 1988.

Lazarus-Yafeh, Hava, "Jewish Knowledge of the Qur'ān” [Hebrew], Sefunot, 5 (1991), pp. 37-47, transl. in Intertwined Worlds. Medieval Islam and Bible Criticism, Princeton, Princeton University Press, 1992, pp. 143-160.

Levy, Joshua, "Sefer Milhamot hashem, Chapter Eleven: The Earliest Jewish Critique of the New Testament", Ph.D. Diss., New York, New York University, 2004.

Limor, Ora, "The Epistle of Rabbi Samuel of Morocco: A Best-Seller in the World of Polemics", in Ora Limor and Guy Stroumsa (eds.), Contra Iudaeos: Ancient and Medieval Polemics Between Christians and Jews, Tübingen, Mohr Siebeck, 1996, pp. 177-194.

March, J., "Ramon Martí y la seva Explanatio simboli Apostolorum", Anuari de l'Institut d'Estudis Catalans, 2 (1908), pp. 443-496. 
Markus, Robert, "The Jew as a Hermeneutic Device: The Inner Life of a Gregorian Topos", in John Cavadini (ed.), Gregory the Great: A Symposium, Notre Dame, University of Notre Dame, 1995, pp. 1-15.

Marsmann, Monika, Die Epistel des Rabbi Samuel an Rabbi Isaak. Untersuchung und Edition, Ph.D. Diss., Munich, Ludwig-Maximilians-Universität, 1971.

Martínez Gázquez, José, "Las glosas en la primera traducción del Alcoran latinus", in Matthias Tischler and Alexander Fidora (eds.), Christlicher Norden - Muslimischer Süden. Ansprüche und Wirklichkeiten von Christen, Juden und Muslimen auf der Iberischen Halbinsel im Hoch- und Spätmittelalter, Münster, Aschendorff, 2011, pp. 141-151.

Meersseman, G., "La Chronologie des voyages et des oeuvres de Frère Alphonse Buenhombre", Archivum Fratrum Praedicatorum, 10 (1940), pp. 77-108.

Merchavia, Ch., "The Hebrew Version of the 'Pugio Fidei' in the Sainte Geneviève Manuscript" [Hebrew], Kiryat Sefer, 51 (1976), pp. 283-288.

Mérigoux, Jean-Marie (ed.), "Contra legem Sarracenorum”, Memorie Domenicane, 17 (1986), pp. 1-144.

Moore, R.I., The Formation of a Persecuting Society: Power and Deviance in Western Europe, 950-1250, Oxford, Blackwell, 2007, $2^{\text {nd }}$ ed.

Muñoz Sendino, José, “Al-Kindi, Apología del cristianismo”, Miscelánea Comillas, 11-12 (1949), pp. 339-460.

Nirenberg, David, Communities of Violence: Persecution of Minorities in the Middle Ages, Princeton, Princeton University Press, 1996.

Pablo de Santa María, Scrutinium Scripturarum, Burgos, Philippum Iuntam, 1591.

Pacios López, A. (ed.), La Disputa de Tortosa, Madrid, CSIC, 1957, 2 vols.

Pakter, Walter, Medieval Canon Law and the Jews, Ebelsbach, Gremier, 1988.

Patrologia Cursus Completus, Series Latina, J.P. Migne (ed.), Paris, J.P. Migne, 1844-1855, 221 vols.

Paudice, Aleida, "On Three Extant Sources of the Qur'an Transcribed in Hebrew”, European Journal of Jewish Studies, 2 (2009), pp. 213-236.

Pedro Pascual (Pseudo-), Sobre la se(c)ta mahometana, Fernando González Muñoz (ed.), Valencia, Universitat, 2011.

Petrus Alfonsi, Diálogo contra los Judíos, María Jesús Lacarra and Klaus-Peter Mieth (eds.), Huesca, Instituto de Estudios Altoaragoneses, 1996.

Petrus Alfonsi, Dialogue Against the Jews, Irven Resnick (trans1.), Washington D.C., Catholic University of America, 2006.

Petrus Venerabilis, Adversus Iudaeorum inveteratam duritiem, Yvonne Freidman (ed.), Turnhout, Brepols, 1985.

Petrus Venerabilis, Schriften zum Islam, Reinhold Glei (ed. and transl.), Altenberge, CIS Verlag, 1985.

Petrus Venerabilis, The Letters of Peter the Venerable, Giles Constable (ed.), Cambridge, Mass., Harvard University Press, 1967, 2 vols.

Piemontese, Angelo Michele, "Il Corano latino di Ficino e i Corani arabi di Pico 
e Monchates", Rinascimento: Rivista del'Instituto Nazionale di Studi sul Rinascimento, 36 (1996), pp. 227-73.

Ragacs, Ursula, "Mit Zaum und Zügel muss Man ihr Ungestüm Bändigen” Ps

32,9. Ein Beitrag zur christlichen Hebraistik und antijüdischen Polemik im

Mittelalter, Frankfurt am Main, Peter Lang, 1997.

Ramon Martí, Capistrum Iudaeorum, Adolfo Robles Sierra (ed. and transl.), Würtzburg, Echter, Altenberge, Telos, 1990-1993, 2 vols.

Ramon Martí, Pugio fidei adversus Mauros et Iudaeos, Leipzig, Heirs of Friedrich Lankisch, at the press of the Johann Wittigav's Widow, 1687; facsimile reprint: Farnborough, Gregg, 1967.

Reinhardt, Klaus and Santiago-Otero, Horacio, Biblioteca Bíblica Ibérica Medieval, Madrid, CSIC, 1986.

Riccoldo da Monte di Croce, Pérégrination en Terre sainte et au Proche-Orient; Lettres sur la chute de Saint-Jean-d'Acre, René Kappler (ed. and transl.), Paris, Champion, 1997.

Robles, Laureano, "En torno a una vieja polémica: El 'Pugio fidei' y Tomás de Aquino", Revista Española de Teología, 34 (1974), pp. 321-350 and 35 (1975), pp. 21-41.

Robles, Laureano, Escritores dominicos de la Corona de Aragón. Siglos XIII-XV, Salamanca, Imprenta Calatrava, 1972.

Rodríguez Bachiller, Ángel, Influencia de la filosofía árabe en el Pugio de Raimundo Martí, Madrid, Casa Hispano-Árabe, 1969.

Samaw'al al-Maghribī, Ifḥ̄m al-yahūd. Silencing the Jews, Moshe Perlmann (ed. and transl.), New York, American Academy for Jewish Research, 1964.

Schreckenberg, Heinz, Die christlichen Adversus-Judaeos-Texte und ihr literarisches und historisches Umfeld (13.-20. Jh.), Frankfurt am Main, Peter Lang, 1994.

Septimus, Bernard, "Petrus Alfonsi on the Cult at Mecca", Speculum, 56 (1981), pp. 517-533.

Steinschneider, Moritz, Catalogus Librorum Hebraeorum in Bibliotheca Bodleiana, Berlin, Welt Verlag, 1931.

Steinschneider, Moritz, Polemische und apologetische Literatur in arabischer Sprache, zwischen Muslimen, Christen und Juden nebst Anhangen verwandten Inhalts, Leipzig, F.A. Brockhaus, 1877.

Szpiech, Ryan, "Citas árabes en caracteres hebreos en el Pugio fidei del dominico Ramón Martí: entre la autenticidad y la autoridad”, Al-Qantara, 32, 1 (2011), pp. 71-107.

Szpiech, Ryan, Conversion and Narrative: Reading and Religious Authority in Medieval Polemic, Philadelphia, University of Pennsylvania Press, 2013.

Szpiech, Ryan, "Converting the Queen: Gender and Polemic in the Book of Ahitub and Șalmon”, Journal of Medieval Iberian Studies, 3, 2 (2011), pp. 203-217.

Szpiech, Ryan, "Libro de las tres creencias", in David Thomas and Alex Mallett 
(eds.), Christian-Muslim Relations: A Bibliographical History, IV: 1200-1350 C.E., Leiden, Brill, 2012, pp. 967-973.

Szpiech, Ryan, "Translation, Transcription, and Transliteration in the Polemics of Raymond Martini, O.P.", in Karen Fresco and Charles Wright (eds.), Translating the Middle Ages, Aldershot, Ashgate, 2012, pp. 171-187.

Tolan, John, "Peter of Cluny on the "Diabolical Heresy of the Saracens", in Sons of Ishmael. Muslims Through European Eyes in the Middle Ages, Gainesville, University Press of Florida, 2008, pp. 46-65.

Tolan, John, Petrus Alfonsi and His Medieval Readers, Gainesville, University Press of Florida, 1993.

Tolan, John, "Saracen Philosophers Secretly Deride Islam”, Medieval Encounters, 8 (2002), pp. 184-208, reprint in Sons of Ishmael. Muslims Through European Eyes in the Middle Ages, Gainesville, University Press of Florida, 2008, pp. 113-132.

Tolan, John, Saracens: Islam in the Medieval European Imagination, New York, Columbia University Press, 2002.

Travelletti, Damien, "Front commun. Raymond Martin, al-Ġazālī et les philosophes", Ph.D. Diss., Fribourg, Switzerland, U. Fribourg, 2011.

Wiersma, Syds, “Aquinas' Theory on Dialogue Put into Practice: Trinity in Raymond Martin", in H. Schoot (ed.), Jaarboek 2005, Utrecht, Thomas Instituut te Utrecht, 2006, pp. 9-41.

Zacour, Norman, Jews and Saracens in the Consilia of Oldradus de Ponte, Toronto, Pontifical Institute of Mediaeval Studies, 1990.

Zorgati, Ragnhild, Pluralism in the Middle Ages. Hybrid Identities, Conversion, and Mixed Marriages in Medieval Iberia, New York, Routledge, 2012.

Recibido: 01/06/2012

Aceptado: 11/01/2013 